\title{
ОБРАЗ УКРАЇНИ У ФРАНЦУЗЬКИХ МЕДІА (НА ПРИКЛАДІ «LE FIGARO»)
}

\author{
Ольга Полумисна \\ Харківський національний університет імені В. Н. Каразіна, \\ майдан Свободи, 4, 61000, Харків, Украӥна \\ e-mail:polumisna.olga@gmail.com \\ https://orcid.org/0000-0002-4289-0588
}

У статті вивчено особливості формування образу України у медіатекстах провідного французького видання «Le Figaro». Авторка ставила за мету дослідити формування образу України у французьких 3MI, а саме - в «Le Figaro», із застосуванням системного аналізу журналістських матеріалів на українську тематику у їхньому проблемно-тематичному аспекті, а також сфокусуватися на теоретичному осмисленні ефективності впливу цих матеріалів на аудиторію французьких реципієнтів, в чиїй уяві постає конкретний образ, який формують французькі видання. У цій публікації розкрито етимологію ключових понять «образ», «імідж»; визначено основні чинники, за допомогою яких формується образ держави, досліджено діяльність «Le Figaro» у цьому напрямі; окреслено образ України на сучасному етапі розвитку держави та проаналізовано публікації на українську тематику, зокрема стосовно спорту, економіки, політики, культури тощо.

Ключові слова: образ; імідж; медіатекст; образ України; позитивний імідж; негативний імідж.

\section{1. Постановка проблеми.}

Сьогодні Україна перебуває на важливому етапі свого становлення. Завдяки Революціям (Помаранчева, Гідності) світ дізнався про нашу державу набагато більше, ніж знав раніше, коли багато хто вважав її частиною Російської імперії. У сучасному міжнародному інформаційному просторі Україна постає як конкурентоспроможна країна, а це впливає на імідж нашої держави, на її авторитет на міжнародній арені.

Чимало учених і журналістів проводять моніторинг іноземних ЗМI, намагаються об’єктивно визначити місце України у світовому рейтингу. А оскільки Україна обрала проєвропейський вектор розвитку, цікаво спостерігати, як це висвітлюють французькі 3МІ. Ці чинники й зумовлюють актуальність нашої роботи.

У статті вперше досліджено особливості формування іміджу України у французьких 3MI, зокрема у медіатекстах такого видання, як «Le Figaro». Аналіз журналістських матеріалів на українську тематику у вищеназваному виданні дає нам змогу зрозуміти, який саме образ України постає перед аудиторією французьких ЗМІ.

(C) Полумисна О., 2020 


\section{2. Теоретичне підгрунтя.}

Теоретичну основу нашої роботи складають праці таких учених, як А. Акайомова, Ю. Бокоч, І. Важеніна, О. Васильконова, А. Гаврилюк, В. Данилов, Г. Даулінг, В. Жулай, Н. Качинська, А. Рожков та ін.

\section{3. Методологічна основа дослідження.}

Методи дослідження випливають 3 потреби оцінити журналістські матеріали на українську тематику, що опубліковані на сторінках видання «Le Figaro». У роботі використано такі методи, як аналітичний (проаналізовано усі складові французьких медіатекстів, визначено тенденції формування іміджу України), синтетичний (поєднано складові французьких медіатекстів у цілісну систему та досліджено їхній взаємозв'язок), структурно-типологічний (систематизовано та класифіковано медіапублікації, згруповано об'єкти дослідження за певним критерієм, а саме проблемно-тематичним).

\section{4. Виклад основного матеріалу дослідження.}

Сьогодні важливим та актуальним $є$ питання образу/іміджу країни і на міжнародній арені, і у внутрішньому контексті. А це залежить від багатьох чинників. Імідж - це авторитет і впливовість держави у всіх сферах їі діяльності. Сприйняття України як держави та українців як нації залежить від багатьох чинників, одним із провідних є засоби масової комунікації та інформації. Саме вони здатні формувати громадську думку, створювати уявні образи і в такий спосіб передбачати суб’єктивне ставлення людини до певної події чи явища. Люди вже звикли мислити образами і сприймають лише їх.

Отже, первинною ланкою, яка формує уяву людини про якусь країну, є образ. Це поняття А. Гаврилюк трактує як сформовану різними інституціями уяву «суб'єкта про об’єкт уяви, що здатен справити на кого-небудь емоційний і психологічний вплив. Саме ця дефініція визначає сукупність характеристик, які відображаються у свідомості людей про певну місцевість 3 притаманними культурними, естетичними, історичними та іншими конкурентними перевагами, які й створюють підгрунтя для формування іміджу»'.

Дуже тісно $з$ поняттям «образ» пов'язано поняття «імідж». Незважаючи на те, що поняття «імідж» використовують уже тривалий час, чіткого та єдиного його визначення немає. Слово «імідж» походить від слова image, що в перекладі з французької мови означає образ. Тлумачний словник Вебстера дає таке визначення: імідж штучна імітація, наслідування або репрезентація зовнішньої форми, манери якогось об'єкта або особи ${ }^{2}$.

Власне, можемо зазначити, що формування іміджу - це процес, спрямований на те, щоб подати суспільству певний образ чого- або кого-небудь 3 певною оцінкою цього образу у вигляді усвідомленої/неусвідомленої думки про цей образ. I все це для того, щоб психологічно привернути увагу аудиторії до якогось об’єкта

\footnotetext{
1 Гаврилюк, А., (2019), «Про ціннісні засади маркетингового конструкту «образ-імідж-бренд-репутація території» як пріоритету державної політики в сфері туризму в Україні», Державне управління. Інвестииії: практика та досвід, № 1, с. 76-83.

2 Webster's New Complete Thesaurus (1995), USA, p. 690.

3 Панасюк, А., (2008), «Формирование имиджа: стратегия, психотехнологии, психотехники», 2-е изд., стер. М., Изд-во Омега-Л, С. 35-38.
} 
Зрозуміло, що імідж є результатом деяких дій, зміст яких визначають певні фактори, з-поміж яких культурні особливості, соціально-економічні процеси, геополітичне становище країни, традиції тощо. Учені пропонують систему, яка складається із комплексу взаємодіючих між собою факторів, називати образом країни. Одним із найвідоміших визначень образу (іміджу) країни є визначення Е. Галумова, згідно з яким це «комплекс об'єктивних, взаємопов'язаних між собою характеристик державної системи (економічних, географічних, національних, культурних, демографічних та ін.), що сформувалися в процесі еволюційного розвитку державності як складної багатофакторної підсистеми світового устрою, ефективність взаємодії ланок якої визначають тенденції соціально-економічних, суспільно-політичних, національно-конфесійних та інших процесів в країні» ${ }^{4}$. Іншими словами, образ країни - це своєрідна база, за допомогою якої визначається те, якої репутації набула країна у свідомості світової спільноти.

Імідж держави як образ, що створюється цілеспрямовано, стосується і спільноти всередині країни, і світової спільноти. Щоб утвердитися на міжнародній арені, країна має подбати передовсім про власний позитивний імідж.

Потрібно розуміти, що залежно від емоційних характеристик, до яких спонукує імідж, його можна розглядати як позитивний (викликає позитивні емоції: шану, любов, повагу) і як негативний (пов'язаний із формуванням негативних емоцій: ворожості, ненависті, зневаги) ${ }^{5}$.

Загалом, від сформованого позитивного іміджу регіону залежать чимало: успішність та конкурентоспроможність регіону при розподілі різноманітних ресурсів, залучення інвесторів, розвиток господарського комплексу, інфраструктури, цілісність та неконфліктність регіону, розвиток соціальної комунікації у регіоні та за його межами ${ }^{6}$ Невдало сконструйований імідж, або такий, що мимовільно виник, здатний стати основою найсильніших інформаційних збоїв у комунікаційних процесах між населенням регіону та зовнішніми спільнотами, руйнування характеристик уявного спільноти та, у підсумку, атомізації суспільства, руйнування або дестабілізації його інституціональної структури, розмивання і руйнування соціальної ідентичності не тільки територіальної, а й соціальної ідентичності загалом

Імідж України є не лише їі стратегічним надбанням, але й важливим показником оцінки для світової спільноти, він також визначає рівень співпраці з іншими державами на міжнародній арені. Важливу роль у конструюванні іміджу країни відіграють закордонні медіаресурси, які, публікуючи інформацію про нашу державу, фактично формують їі образ. Особливо актуальними, на нашу думку, є проблемно-тематичні домінанти (політика/економіка, культура, спорт, наука, соціум/суспільство) у французьких 3MI, а саме - в «Le Figaro».

4 Николаева, Ю., (2009), «Межкультурная коммуникация и международный культурный обмен», Культурологія, с. 367-369.

5 Акайомова, А., (2011), «Комунікативні властивості іміджу та його класифікація», Віче, № 22, URL: http://veche.kiev.ua/journal/2798/ (дата перегляду 16 жовтня 2019).

6 Васильконова, Е., (2014), «Розвиток теорії іміджу територій як активного інструменту регіонального менеджменту», Бізнесінформ, № 12, с.463-468.

7 Еремеев, С., (2009), «Формирование имиджа региона как инструмента управления его развитием», Автореферат кандидатской диссертации (экономика и управление народным хозяйством (рег. экономика; маркетинг), Москва, 24 с. 
Однією з публікацій на політичну тематику, розміщених на сайті видання із тегом «Україна», $є$ кореспонденція про обмін полоненими між Росією та Україноюв I хоча українських полонених 35 , на першому фото одразу бачимо Олега Сенцова, людину, яку знає увесь світ, яка не скорилася Кремлю. У цьому матеріалі автор акцентує на постатях тих, кого звільнили, дає коротку характеристику найвідомішим із них. Про українського президента і його роль у цьому звільненні у матеріалі не згадують, йдеться лише про полонених. Можна прочитати також закиди стосовно того, що українська влада не мала б віддавати Росії головного підозрюваного у справі збиття Боїнгу MH 17: «Les Pays-Basontexhorté envain l'Ukraine à nepas échanger ceté moin vers la Russie» («Нідерланди закликали Україну не обмінювати цього свідка на Росію»)9. Кореспонденція містить чимало зображень та скрінів сторінок із соціальних мереж, на них - звільнені українці та один російський журналіст. На кількох фото - Олег Сенцов. Їх було розміщено у Twitter на сторінці Stephan Siohan, показано, як Сенцов виходить із літака, його зустрічає велика кількість людей. Маємо напис «Oleg\#Sentsovisfreeandhascomebackto\#Ukraine» (Олег Сенцов вільний і повернувся до України). У цьому тексті і фото, і вербальна частина утворюють цілісний матеріал. Звісно, ця ілюстрація вплинула на рейтинговість публікації, багатьох читачів цікавив факт повернення саме Олега Сенцова.

Негативне враження справляє наступний матеріал під заголовком «Україна: Брюссель допомагає Зеленському» ${ }^{10}$. У тексті заакцентовано на недосвідченості В. Зеленського, зокрема на тому, що він комік і не знає всіх політиків: «Aidons le soldat Zelensky! Tel est le mot d'ordre qui se dessine dans l'Union européenne un mois après l'élection du nouveau chef d'État ukrainien, un ancien comédien ignorant tout de la politique et sommé d'enfiler en quelques jours des habits de président» («Допоможемо рядовому Зеленському! Це гасло, яке з'являється в Європейському Союзі через місяць після обрання нового українського глави держави, колишнього коміка, невігласа у політиці, що за кілька днів одягнувся у президента» ${ }^{11}$. Його беруть на кпини, аналізуючи ролики, у яких він тренується у тренажерному залі, прогнозують йому складну дорогу, оскільки він стає президентом країни, яка перебуває у стані війни. Публікацію ілюструє фото, яке у негативному світлі показує українського президента, коли він, зігнувшись, подає руку одному з представників Брюсселя. Складається враження, що В. Зеленський визнає вищість Євросоюзу, ніби щось просить у них, видається дуже невпевненим. Подію зафіксовано у такий момент, аби показати українського президента у невигідному, принизливому становищі, що негативно впливає на сприйняття образу України та їі лідерів на міжнародній арені.

Наступна публікація має назву «Україна: початок президентства Зеленського» ${ }^{12}$. У ній ідеться про те, що В. Зеленський має невдовзі представити свою коман-

${ }^{8}$ Qui sont les prisonniers echanges par Kiev et Moscou?, (2019), Le Figaro, URL: https://www.lefigaro. fr/international/qui-sont-les-prisonniers-echanges-par-kiev-et-moscou-20190907 (дата перегляду 28 жовтня 2019)

9 Там само.

${ }^{10}$ Vigne, N., (2019), «Ukraine: Bruxelles au secours de Zelensky», Le Figaro, URL: https://www.lefigaro. fr/international/ukraine-bruxelles-au-secours-de-zelensky-20190531 (дата перегляду 26 жовтня 2019)

${ }^{11}$ Там само.

12 Siohan, S., (2019), «Ukraine: debut de la presidence Zelensky», Le Figaro, URL: https://www.lefigaro. fr/international/ukraine-debut-de-la-presidence-zelensky-20190519 (дата перегляду 26 жовтня 2019) 
ду. Про нового президента говорять, називаючи його «невідомим політичним об'єктом», який «не має сили в парламенті», «його партія «Слуга народу» є лише назвою відомого серіалу», набір голосів у 73\% став можливим лише через саму невизначеність кандидата. До того ж чимало таких коментарів ми чуємо від українських експертів, на яких покликуються у французькому виданні. Складається враження, що самі українці створюють собі негативний імідж, який поширюється за межами нашої держави. I журналісти, і експерти мають чітко стежити за своїми коментарями, думками, які активно поширюються у ЗМI, адже саме 3 них іноземні медіа беруть для себе інформацію про нас. Цю публікацію супроводжує фото, на якому В. Зеленський, схрестивши на грудях руки і зігнувшись, спідлоба дивиться кудись. Вимальовується образ людини невпевненої, яка чогось боїться і вагається. У цьому випадку ми не можемо говорити про єдність зображення та змісту, оскільки матеріал породжує суперечливі думки: вирішується, хто приходить до влади, визначаються партії, які будуть представлені в парламенті, йдеться про П. Порошенка, який втрачає голоси, акцентується увага на тому, хто ж переможе: прозахідні реформатори 3 гарною репутацією чи люди олігарха Коломойського, навіть про те, що «Україна - це держава, де абсолютно все можливо», тобто така собі невизначеність, хаос. Вважаємо, що це зображення негативно впливає на формування образу України в очах світової спільноти.

Публікацій на тему культури дуже мало. Можна назвати матеріал, розміщений у «Le Figaro» в розділі «Подорожі», у якому йдеться про красу Києва, його культурно-історичні надбання ${ }^{13}$. Автор матеріалу захоплюється величчю і красою столиці України, говорить про її незалежність, про поступове, повільне відродження демократії: «Honoré de Balzac la sur nommait la «Rome du Nord», et bien des voyageurs la dé peindraient aujourd'hui comme une «Berlin à la mode slave»: des trésors d'architecture miraculeusement épargnés parles drames de l'Histoire, et une capitale où prend place depuis l'indépendance de 1991 une agitation démocratique cahoteuse propreaux sociétés qui, lentement, seréapproprient liberté, pluralisme et suffrage universel» («Оноре де Бальзак назвав його «Північним Римом», і чимало мандрівників сьогодні описують його як «Берлін по-слов'янськи»: архітектурні скарби, дивом врятовані історичними драмами, і столиця, де з часів незалежності 1991 року почалася бурхлива демократична агітація, властива суспільству, яке повільно відновлює свободу, плюралізм і загальне виборче право» ${ }^{14}$. Акцент зроблено на майдані Незалежності, оскільки саме це місце було осередком революційних звершень, що сприяло усуненню В. Януковича з його посту. Про ці події, підкреслює автор, нагадують фото загиблих під час обстрілів. Описано красу Софійського собору, який ЮНЕСКО вписала до всесвітніх надбань, Андріївський спуск із його картинами й вишивками. Рено Тоф’є, автор публікації, захоплено і цікаво розповідає про нашу столицю, що, звісно, позитивно впливає на сприйняття нашої держави поза її межами, та привертає увагу туристів до України.

Спортивна тематика доволі широко представлена на сайті видання «Le Figaro», i Україна часто фігурує у цьому контексті. Однією з перших публікацій, присвячених спорту, із тегом «Україна», став матеріал під заголовком «Великий успіх України у

\footnotetext{
${ }_{13}$ Toffier, R., (2019), «Echappee belle a Kiev, capital de l'Ukraine», Le Figaro, URL: https://www.lefigaro. fr/voyages/echappee-belle-a-kiev-capitale-de-l-ukraine-20190806 (дата перегляду 20 жовтня 2019)

${ }_{14}$ Там само.
} 
боротьбі з Литвою» ${ }^{15}$. Автор із захопленням розповідає, як українські футболісти закріпили першість України у групі В й стали четвертими з п'яти у гонці за кваліфікацію Євро-2020. Цей факт, звісно, позитивно впливає на образ України, показує іiї як країну, де живуть вольові та цілеспрямовані люди, здатні на високі спортивні досягнення.

Замітку супроводжує фото із соціальної мережі Twitter, сторінка Української асоціації з футболу, де зображені українські футболісти, які обіймаються та радіють перемозі. На першому плані зображено рахунок та піктограми із прапорами. Ця ілюстрація з рахунком та символічним зображенням українського прапора формує позитивний імідж нашої держави - України-переможниці.

\section{5. Результати і перспективи подальших досліджень.}

Як бачимо, у публікаціях «Le Figaro» використовують фотоілюстрації, що дискредитують українських лідерів, зокрема В. Зеленського, послуговуються різними принизливими висловами. Найбільше матеріалів тут саме на політичну/економічну тематику. Щодо висвітлення питань культури, то публікацій на цю тему дуже мало, розвиток освіти/науки в Україні взагалі, складається враження, не цікавить французів. Усе це свідчить про те, що для французьких медіа актуальними є лише політичні перипетії, які стосуються України, і майже не цікавить науковий розвиток нашої держави, вони його абсолютно не висвітлюють.

\section{6. Висновки.}

Проаналізувавши публікації «Le Figaro», ми дійшли висновку, що у цьому виданні $є$ публікації з позитивними і негативними конотаціями. Україна в матеріалах «Le Figaro» постає позитивною в контексті спортивних досягнень та культурно-історичної привабливості, хоча особливо на цьому не наголошено, натомість політичні казуси, які трапляються в Україні, дуже активно поширюються і набувають розголосу.

\section{СПИСОК ЛІТЕРАТУРИ}

1. Акайомова, А., (2011), «Комунікативні властивості іміджу та його класифікація», Biче, № 22, URL: http://veche.kiev.ua/journal/2798/ (дата перегляду 16 жовтня 2019).

2. Васильконова, Е., (2014), «Розвиток теорії іміджу територій як активного інструменту регіонального менеджменту», Бізнесінформ, № 12, с. 463-468.

3. Гаврилюк, А., (2019), «Про ціннісні засади маркетингового конструкту «образ-імідж-бренд-репутація території» як пріоритету державної політики в сфері туризму в Україні», Державне управління. Інвестиції: практика та досвід, № 1, c. $76-83$.

4. Еремеев, С., (2009), «Формирование имиджа региона как инструмента управления его развитием», Автореферат кандидатской диссертации (экономика и управление народным хозяйством (рег. экономика; маркетинг), Москва, 24 с.

5. Николаева, Ю., (2009), «Межкультурная коммуникация и международный культурный обмен», Культурологія, с. 367-369.

${ }^{15}$ Large succes pour l'Ukraine face a la Lituanie, (2019), Le Figaro, URL: https://sport24.lefigaro.fr/ football/euro-2020/fil-info/large-succes-pour-l-ukraine-face-a-la-lituanie-972775 (дата перегляду 19 жовтня 2019) 
6. Панасюк, А., (2008), Формирование имиджа: стратегия, психотехнологии, психотехники, 2-е изд., стер. М., Изд-во Омега-Л, С. 35-38.

7. Large succes pour l'Ukraine face a la Lituanie, (2019), Le Figaro, URL: https://sport24. lefigaro.fr/football/euro-2020/fil-info/large-succes-pour-l-ukraine-face-a-la-lituanie-972775 (дата перегляду 19 жовтня 2019)

8. Qui sont les prisonniers echanges par Kiev et Moscou?, (2019), Le Figaro, URL: https:// www.lefigaro.fr/international/qui-sont-les-prisonniers-echanges-par-kiev-et-moscou-20190907 (дата перегляду 28 жовтня 2019)

9. Siohan, S., (2019), «Ukraine: debut de la presidence Zelensky», Le Figaro, URL: https:// www.lefigaro.fr/international/ukraine-debut-de-la-presidence-zelensky-20190519 (дата перегляду 26 жовтня 2019)

10. Toffier, R., (2019), «Echappee belle a Kiev, capital de l'Ukraine», Le Figaro, URL: https://www.lefigaro.fr/voyages/echappee-belle-a-kiev-capitale-de-l-ukraine-20190806 (дата перегляду 20 жовтня 2019)

11. Vigne, N., (2019), «Ukraine: Bruxelles au secours de Zelensky», Le Figaro, URL: https:// www.lefigaro.fr/international/ukraine-bruxelles-au-secours-de-zelensky-20190531 (дата перегляду 26 жовтня 2019)

12. Webster's New Complete Thesaurus (1995), USA, p. 690.

\section{REFERENCES}

1. Akaiomova, A., (2011), «Communicative properties of the image and its classification», Viche, № 22, URL: http://veche.kiev.ua/journal/2798/ (Date of revision 16 October 2019).

2. Vasylkonova, E., (2014), «Development of the theory of image of territories as an active tool of regional management», Biznesinform, № 12, s. 463-468.

3. Havryliuk, A., (2019), «On the Value Principles of the Marketing Image-ImageBrand-Reputation of Territory as a Priority of State Tourism Policy in Ukraine», Derzhavne upravlinnia. Investytsii: praktyka ta dosvid, № 1, s. 76-83.

4. Eremeev, S., (2009), «Formation of the image of the region as a tool for managing its development», Avtoreferat kandydatskoi dyssertatsyy (эkonomyka y upravlenye narodnbim khoziaistvom, Moscow, $24 \mathrm{~s}$.

5. Nykolaeva, Yu., (2009), «Intercultural communication and international cultural exchange», Kulturolohiia, s. 367-369.

6. Panasiuk, A., (2008), Formirovanie imidzha: strategiya, psihotekhnologii, psihotekhniki, 2-e yzd., ster. M., Yzd-vo Omeha-L, S. 35-38.

7. Large succes pour l'Ukraine face a la Lituanie, (2019), Le Figaro, URL: https:// sport24.lefigaro.fr/football/euro-2020/fil-info/large-succes-pour-l-ukraine-face-a-la-lituanie-972775 (Date of revision 19 October 2019))

8. Qui sont les prisonniers echanges par Kiev et Moscou?, (2019), Le Figaro, URL: https://www.lefigaro.fr/international/qui-sont-les-prisonniers-echanges-par-kiev-etmoscou-20190907 (Date of revision 28 October 2019)

9. Siohan, S., (2019), «Ukraine: debut de la presidence Zelensky», Le Figaro, URL: $\quad$ https://www.lefigaro.fr/international/ukraine-debut-de-la-presidence-zelensky-20190519 (Date of revision 26 October 2019) 
10. Toffier, R., (2019), «Echappee belle a Kiev, capital de lUkraine», Le Figaro, URL: https://www.lefigaro.fr/voyages/echappee-belle-a-kiev-capitale-de-l-ukraine-20190806 (Date of revision 20 October 2019)

11. Vigne, N., (2019), «Ukraine: Bruxelles au secours de Zelensky», Le Figaro, URL: $\quad$ https://www.lefigaro.fr/international/ukraine-bruxelles-au-secours-de-zelensky-20190531 (Date of revision 26 October 2019)

12. Websters New Complete Thesaurus (1995), USA, p. 690.

\title{
UKRAINE'S IMAGE IN FRENCH MEDIA (BASED ON LE FIGARO)
}

\author{
Olha Polumysna \\ V.N.Karazin Kharkiv National University, \\ 4 Svobody Sq., 61000, Kharkiv, Ukraine \\ e-mail:polumisna.olga@gmail.com \\ https://orcid.org/0000-0002-4289-0588
}

The article presents a research on the formation of Ukraine's image in the mediatexts of the leading French newspaper Le Figaro. The aim of the work is to study Ukraine's image formed on the pages of French mass media, in particular the paper Le Figaro, by a systemic analysis of the journalistic data about Ukraine in their problem-thematic aspect as well as by theoretical comprehension of the effectiveness of their impact on French readers, whose imagination produces a particular image formed by the French newspaper. The article reveals the etymology of the key notions like image, defines the main factors that determine the formation of a country's image and analyses the French media Le Figaro. The image of Ukraine in its present stage of development is outlined and the articles about Ukraine concerning the main aspects such as sports, economics, politics, culture etc are studied. It is established that the analysed newspaper has articles with both positive and negative connotations, so Ukraine is represented as independent and self-reliant on the one hand and as vulnerable, dangerous on the other. The prevalence of articles about politics and economics is accentuated.

The methods of research are based on evaluation of the journalistic data about Ukraine published on the pages of Le Figaro newspaper. The methods used in the article include the analytical method (all the components of the part of French mediatexts have been analysed and the trends of Ukraine's image formation have been defined), synthetic (the constituents of French mediatexts have been combined into an integral system, their interconnection has been studied), structural-typological (mediapublications have been systemised and classified by grouping the objects of the study by the problem-thematic parameter).

Key words: image, mediatext, Ukraine's image, positive image, negative image. 